\title{
任意の位置での簡単なジェスチャによる家電操作システム
}

\author{
顔 世荀"1，池 勇勳"2，梅田 和昇 ${ }^{* 3}$
}

\section{Operation system for home appliances with simple gestures at arbitrary position}

\author{
Shixun YAN ${ }^{* 1}$, Yonghoon $\mathrm{JI}^{* 2}$ and Kazunori UMEDA*3 \\ ${ }^{* 1, * 3}$ Department of Precision Mechanics, Chuo University \\ 1-13-27 Kasuga, Bunkyo-ku, Tokyo 112-8551, Japan \\ ${ }^{* 2}$ Graduate School of Advanced Science and Technology, Japan Advanced Institute of Science and Technology \\ 1-1 Asahidai, Nomi, Ishikawa 923-1292, Japan
}

Received: 1 September 2020; Revised: 15 March 2021; Accepted: 13 May 2021

\begin{abstract}
In this paper, a novel system that remotely operates home appliances is proposed. The system is based on a command space associated with the operation of the home appliance. Thus, a user is able to control the system with simple hand gestures at an arbitrary position. In the system, a pseudo relative coordinate system which is a user-definable coordinate system is applied. The hand waving gesture is detected from the images acquired by multiple cameras installed in the room. Then, the position of hand waving gesture is calculated using the stereo measurement. Next, the pseudo relative coordinate system is defined according to the calculated position. Therefore, it is possible to operate home appliances freely at an arbitrary position chosen by the user. In addition, home appliances are operated using a hand positioning gesture that requires less operation time and less burden than a hand waving gesture. The hand positioning gesture is detected using the frame subtraction and the background subtraction. Experiments verify the operation accuracy and operation time for commands using the proposed system for detailed operations such as TV channel switching.
\end{abstract}

Keywords : Gesture recognition, Human interface, User-definable coordinate system, Command space, Intelligent room

\section{1. 緒言}

日常生活において久かすことのできない家電製品は近年，より多機能化，高性能化している．しかし，その一 方で操作の複雑化という問題も生じている．また，社会現象に着目すると，高齢化社会の時代を迎えつつある. このような時代において，多くの高齢者は複雑な操作を必要とする機器に対し，苦手意識を持つ．そのため， ヒ ユーマンインタフェースが優れた操作システムに対する需要が高まりつつある. 近年，家電製品の様に人に身近 な製品を人のジェスチャを用いて直感的に操作することを目的とした研究が多くなされている(森，佐藤，2008) (Hsieh et al., 2010) (Muranaka et al., 2020) (Trong et al., 2019). また，最近では音声認識による家電操作も様々な領域 で発展している(Bt Aripin and Othman, 2014). 音声認識による家電操作は，複雑な操作を必要としないなどのメリ ットがあるが，うるさい環境では周囲の音の影響を受ける恐れがあり，また静かな環境で操作者が音声を発した くない場合も考えられる。一方で，画像処理によるジェスチャ認識は，環境の照明などの影響を受けるが，上記 の音に関する問題はない．まだ，最近では画像処理で簡単に使用できる無線 IP カメラなども販売されている. そこで本研究では，ジェスチャを用いて家電操作を行うシステムに着目する.

入江らは，高齢者がリモコンなどの小さいボタンを操作するのが苦手であるという問題を解決するため，室内 に複数台のカメラを設置したインテリジェントルームを構築した(入江他，2007)。このシステムでは，屋内の任

No.20-00310 [DOI:10.1299/transjsme.20-00310], J-STAGE Advance Publication date : 24 May, 2021

${ }^{* 1}$ 正員, 中央大学大学院 理工学研究科 精密工学専攻（广112-8551 東京都文京区春日 1-13-27)

*2 正員, 北陸先端科学技術大学院大学 先端科学技術研究科（干923-1293 石川県能美市旭台 1-1）

*3 正員, フェロー, 中央大学 理工学部 精密機械工学科

E-mail of corresponding author: karasu@sensor.mech.chuo-u.ac.jp 
意の場所から人のジェスチャによる機器の操作が可能である. しかし，このシステムを操作するためには，操作 者が複数種類のジェスチャをすべて記憶せざるを得ない，浅野らは，家電操作のコマンドを関連づけた仮想の空 間（以降，コマンド空間と呼ぶ）を屋内に配置し，その空間で手振りを行うことで家電操作を行うことができる システムを提案した(浅野他, 2013). さらに, Kano らはコマンド空間の階層化を提案し, 少数のコマンド空間で, リモコン操作でも手間がかかる複雑な家電操作を実現した(Kano et al., 2018). しかし, これらのシステムではコマ ンド空間が固定されているため，操作位置が限定されてしまう。そこで，今村らはユーザの 3 次元形状における 主成分分析により定義される相対座標系を提案した. ユーザに固定された相対座標系を基準にコマンド空間を設 置することで, 部屋中任意の場所での操作を可能にした(今村他, 2013). しかし, このシステムでは, 相対座標 系を高精度に設定するのが困難であり，その結果コマンドの認識率が低くなる．Muranaka らはウェブカメラと OpenPose を用いてジェスチャ認識及び家電操作を可能にした(Muranaka et al., 2020). しかし，このシステムでは, 入江ら(入江他, 2007)のシステムと同様に操作種類分のジェスチャを記憶する必要がある. Kaneda らはマイクロ 波ドップラセンサを用いて二種類のジェスチャ認識を可能にした(Kaneda et al., 2015). しかし，このシステムは特 殊なセンサが必要である. Trong らは，スマートウォッチのモバイルセンサと深層学習を用いて複雑なジェスチ ヤの検出を実現した(Trong et al., 2019). しかし, このシステムでは常にスマートウォッチを装着する必要がある.

これらの問題を踏まえ, 筆者らは擬似相対座標系という概念を提案寸る(Yan et al., 2019). 複数のカメラ画像か ら人の手振りを検出し, その位置で擬似相対座標系を展開することで, 部屋中任意の場所での家電操作を可能に する. (Yan et al., 2019) では，家電製品を操作する際にも手振りを用いているが，処理時間がかかってしまう.さ らに, 家電製品を操作する際に何度も手を振る必要があるため, ユーザが疲労する可能性がある. これに対し, 視線情報を使用し家電製品を操作する方法がある(Nakayama et al., 2012). しかし, 部屋の位置に関わらず安定に 視線を検出することは難しく, 各操作に必要な時間も評価されていない. この問題を解決するため, 本研究では,

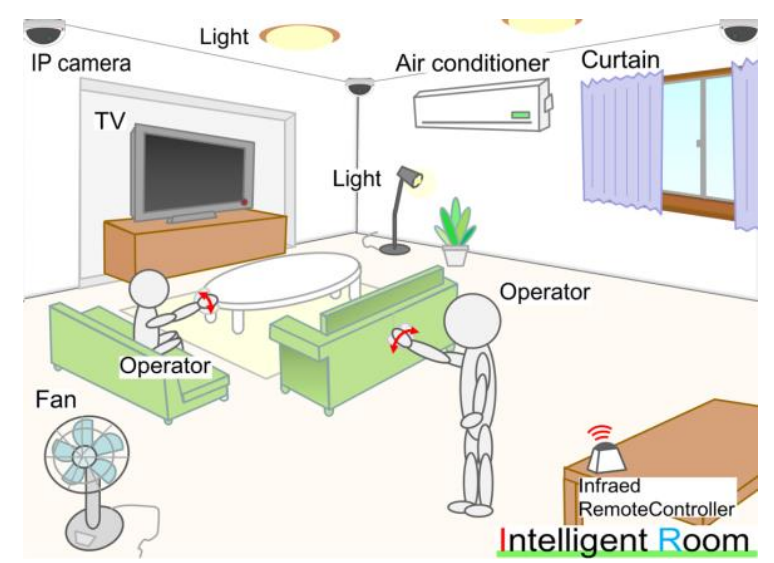

Fig. 1 Conceptual diagram of an intelligent room.

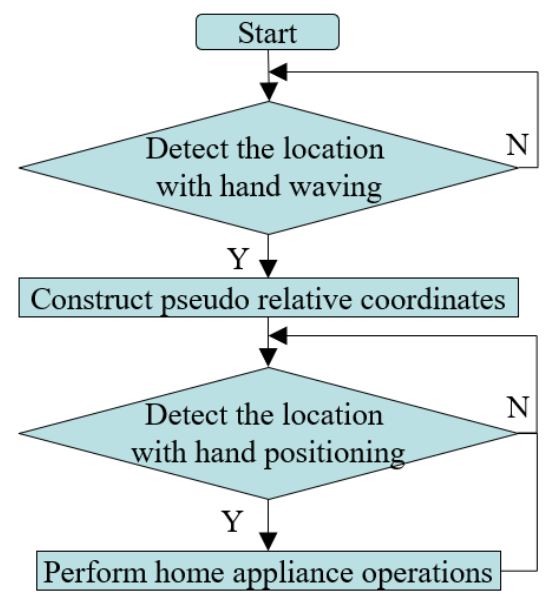

Fig. 2 System flowchart. 


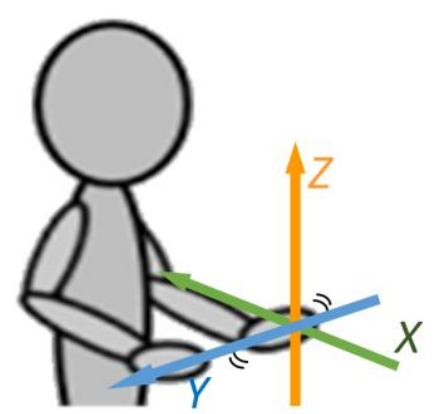

Fig. 3 Pseudo-relative coordinate system based on the position of hand waving.

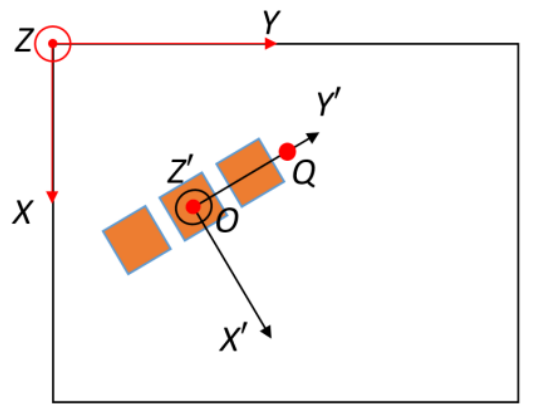

Fig. 4 Relationship between absolute coordinate system and pseudo-relative coordinate system. Orange rectangles represent the command spaces.

ユーザに負担をかけずに，簡単なジェスチャで家電操作できる新しいシステムを提案する．具体的には，手を 1 箇所に置いて短時間静止する手かざしジェスチャを利用する.

\section{2. 提案システムの概要}

本研究で扱うシステムは，屋内の家電機器を人のジェスチャのみで操作可能にしたシステムであり，リビング やオフィスなどでの使用を想定している．提案システムの概念図とフローチャートを図 1 と図 2 に示寸. 提案す るシステムにおける操作手順は以下の通りである。 まず, ユーザが異なる位置で 2 回手振りジェスチャを実行し, 擬似相対座標系を定義する．コマンド空間は，擬似相対座標系に基づいて構築される．次に，ユーザはコマンド 空間で手かざしを行うことで，家電を操作する．操作完了後は，特定の位置で手かざしを行うことで，コマンド 空間や擬似相対座標系を消去する.

\section{3. 擬似相対座標とコマンド空間}

\section{$3 \cdot 1$ 擬似相対座標系}

擬似相対座標系とは，ユーザが任意の場所で定義する座標系であり，ユーザが移動しても，定義された位置に 固定される. 人の手振りを検出した 3 次元座標から擬似相対座標系を展開し，その擬似相対座標を基準にしてコ マンド空間を設置することで, 部屋中任意の場所での家電操作が可能になる．擬似相対座標系はユーザが複数回 手振りを遂行して, 得られた 3 次元座標で設定される. このとき, 手振りは左右どちらの手でも実行可能である. 擬似相対座標系の概略図を図 3 に示寸. 本論文では, 一回目の手振りにおける 3 次元座標を擬似相対座標系の原 点とコマンド空間の中心とする.また,一回目と二回目の手振りにおける 3 次元座標同士を結んだ軸を $Y$ 軸とし, 高さ方向を $Z$ 軸, $Y$ 軸と $Z$ 軸の外積を $X$ 軸とする.

一回目の手振りの 3 次元位置を $O\left(x_{1}, y_{1}, z_{1}\right)$, 二回目の位置を $Q\left(x_{2}, y_{2}, z_{2}\right)$ とする. ここで, コマンド空間を水平 に展開するため, $z_{2}$ の值を $z_{1}$ と等しくする. 絶対座標 $(x, y, z)$ と擬似相対座標 $\left(x^{\prime}, y^{\prime}, z^{\prime}\right)$ の関係を図 4 と次式に示寸.

$$
\begin{aligned}
& \left(\begin{array}{l}
x^{\prime} \\
y^{\prime} \\
z^{\prime}
\end{array}\right)=\mathbf{R}\left(\begin{array}{l}
x \\
y \\
z
\end{array}\right)+\left(\begin{array}{l}
x_{1} \\
y_{1} \\
z_{1}
\end{array}\right) \\
& \mathbf{R}=\left(\begin{array}{ccc}
\frac{y_{2}-y_{1}}{\sqrt{\left(x_{2}-x_{1}\right)^{2}+\left(y_{2}-y_{1}\right)^{2}}} & \frac{x_{1}-x_{2}}{\sqrt{\left(x_{2}-x_{1}\right)^{2}+\left(y_{2}-y_{1}\right)^{2}}} & 0 \\
\frac{x_{2}-x_{1}}{\sqrt{\left(x_{2}-x_{1}\right)^{2}+\left(y_{2}-y_{1}\right)^{2}}} & \frac{y_{2}-y_{1}}{\sqrt{\left(x_{2}-x_{1}\right)^{2}+\left(y_{2}-y_{1}\right)^{2}}} & 0 \\
0 & 0 & 1
\end{array}\right)
\end{aligned}
$$




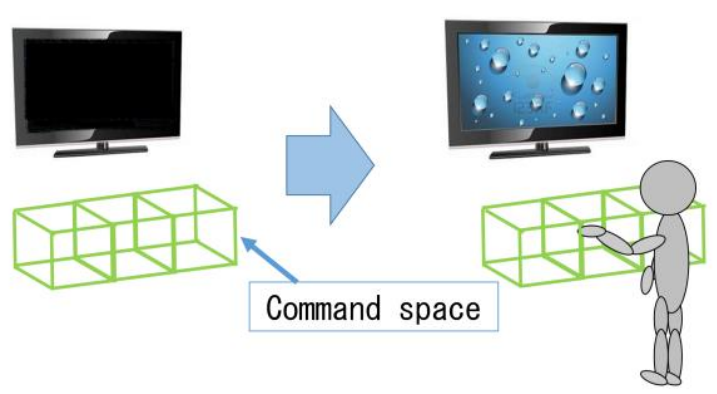

Fig. 5 Conceptual image of the command space.

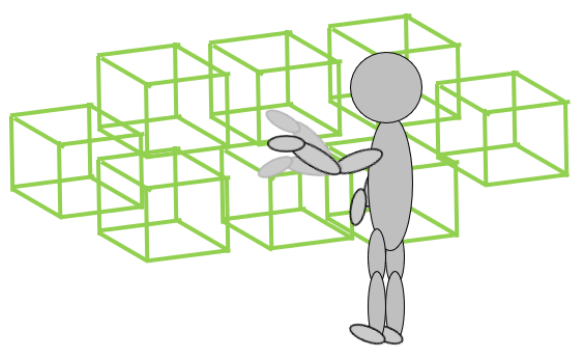

Fig. 6 Arrangement of the command spaces.

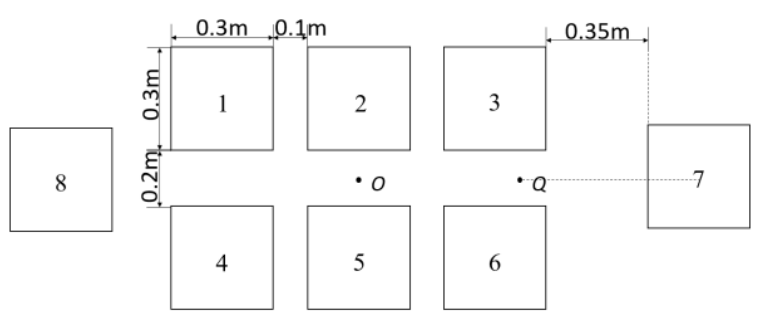

Fig. 7 Front view of the command spaces.

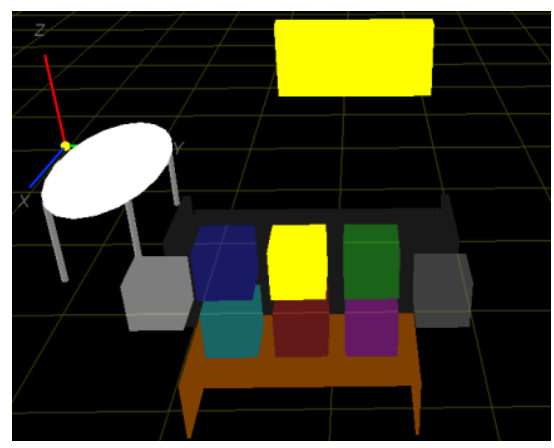

Fig. 8 Command space display.

ただし，R は絶対座標系と擬似相対座標系間の回転行列である.

\section{$3 \cdot 2$ コマンド空間}

コマンド空間とは, 家電操作と関連付けられた仮想空間である. 空間に情報を埋め込んだ空間メモリ (Niitsuma et al., 2012)の考え方を用いて, 家電操作における特定のコマンドをコマンド空間に関連付ける(浅野他，2013) (今村 他, 2013). このコマンド空間で手かざしを行うことで, 関連付けられた家電の特定のコマンドを実行可能である. 本研究におけるコマンド空間のイメージを図 5 に示寸. 図 5 のイメージ図では, 中央にあるコマンド空間が TV の ON/OFF コマンドに関連付けられており，そのコマンド空間で手かざしを行うことで，TVの ON/OFF の操作 を行っている.

本論文では，コマンド空間を図 6 に示すように計 8 個配置する. 一回目の手振りによるコマンド空間の原点 $O$ は図 7 (正面図) に示すように全空間の中心位置である. また, 図 7 の点 $Q$ は, 二回目の手振りによる位置を示 寸. 1 番から 6 番コマンド空間は家電を操作用のコマンド空間である. 7 番コマンド空間は階層をリセットするた めの空間, コマンド空間の左の 8 番コマンド空間はコマンド空間と擬似相対座標系を消去するための空間である.

展開されたコマンド空間の相対位置をユーザが直観的に分かりやすいように提示する方法として, 図 8 に示す ような画面をディスプレイやプロジェクタで表示する．ここで，黄色の長方形は操作対象の家電を示す. 


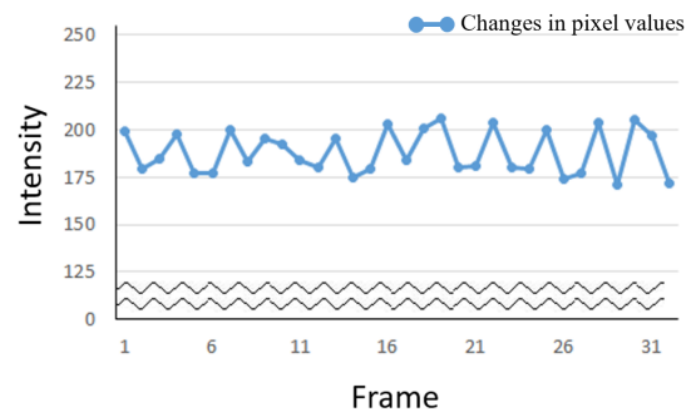

Fig. 9 Changes in pixel values corresponding to hand waving.

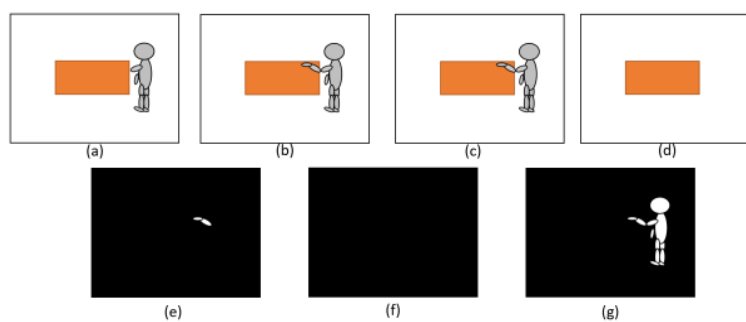

Fig. 10 Illustration of background subtraction and frame subtraction: (a) frame $k$-1, (b) frame $k$, (c) frame $k+1$, (d) background image, (e) frame subtraction between (a) and (b), (f) frame subtraction between (b) and (c), and (g) background subtraction result on (c).

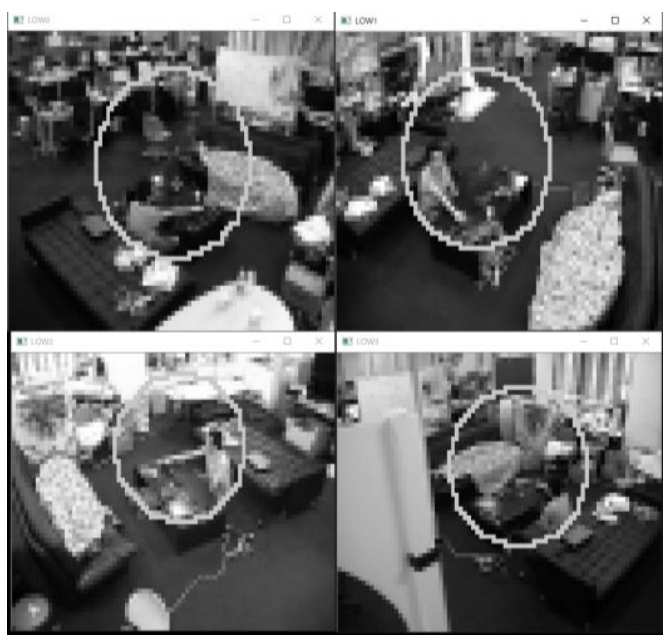

Fig. 11 The range of detection

\section{4. ジェスチャの検出}

この章では，擬似相対座標系の設置時に使用する手振り動作とコマンド空間を操作するための手かざし動作の 検出手法について説明する.

\section{$4 \cdot 1$ 手振り検出}

インテリジェントルーム内のカメラから取得した画像を低解像度化し，画素值の時系列変化に対して高速フー リエ変換 (FFT : fast Fourier transform) を行うことで, 周期的な動作である手振りの検出を行う（入江, 梅田, 2003). 手振り領域に対応する画素では，図 9 に示すように濃淡值が変化する。この濃淡值の変化は，周期的な変化であ るため, FFT を行うことで周波数と振幅の算出が可能である.FFTにより求めたスペクトルから特徴空間を定め, 手振りに対しクラスタリングをする，手振りが行われた画素では，手振りの周期に近い周期の成分は大きく，遠 
い周期の成分は小さくなる特徴を持っている. そこで, スペクトルにおける最大值 $G_{\max }$ と平均值の $G_{\text {avg }}$ を特徵量 と寸る. $G_{\text {max }}, G_{\text {avg }}$ はそれぞれ次式のように与えられる.

$$
\begin{aligned}
& G_{\max }=\max _{n}\left(\left|\sum_{k=1}^{N-1} l_{k} W_{N}^{n k}\right|\right) \\
& G_{\text {avg }}=\frac{2}{N} \sum_{n=2}^{\frac{N}{2}} G_{n}
\end{aligned}
$$

ただし， $N$ はサンプリング数，Wは Discrete Fourier Transform の回転子を表す．ここで，スペクトルの周波数 0 は直流成分, 周波数 1 は照明のちらつきなどによって大きくなる傾向があるため, スペクトルの平均值の計算に 含まない. 手振りの判断基準は次式の通りである.

$$
G_{n}>t \times \operatorname{Avg}(n>1)
$$

ただし, $n$ を手振り動作の周波数とする, $t$ は手振りと判断する閾值である. 以上の手法を複数のカメラで行い, エピポーラ拘束を満たす画素を手振り画素として特定する. その後, ステレオ計測により手振りの 3 次元座標を 求める.

\section{$4 \cdot 2$ 手かざし検出}

コマンド空間を構築した後, 家電製品の操作は, 手振りではなく手かざしの位置に基づいて行う. 低解像度化 された画像に対し，背景差分とフレーム間差分を用いて，手かざしの検出を行う．手かざし検出処理の流れを図 10 に示す. まず, フレーム $k$-1 の画像（図 10(a)）とフレーム $k$ の画像（図 10(b)）を差分する, 図 10(e)に示した 白いピクセルはフレーム間差分の結果である. 次に, フレーム $k$ の画像とフレーム $k+1$ の画像 (図 10(c) ) で差分 を取る. 手かざしが行われた時には, 図 10(f)に示したように差分領域が生じない. その後, フレーム $k+1$ の画像 に対し背景差分を実行する (図 10(g)) . 以上の手順を用いて, 図 10(e), 図 10(f), 図 10(g)の結果が白, 黒, 白の

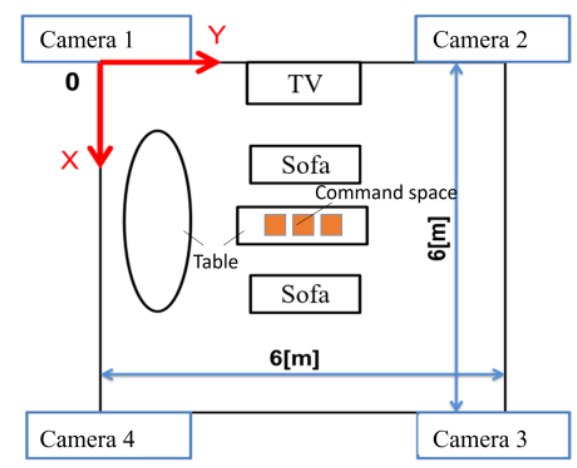

Fig. 12 Experimental environments of the home appliance operation system.
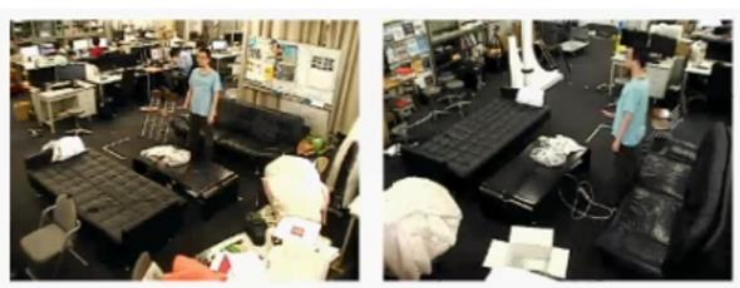

Camera 1

Camera 4

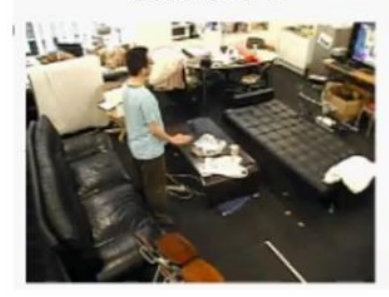

Camera 2

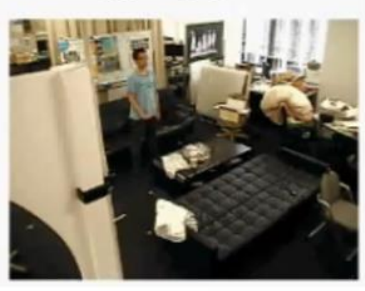

Camera 3

Fig. 13 Experimental situation. 
順で変化した領域を，手かざしが発生した領域として検出する. 最後に, ステレオ計測により, 手かざしの 3 次 元座標を求める.家電製品の操作は手かざしの位置に配置されているコマンド空間に応じて実行される.そこで, 図 11 に示した円内部の範囲のみで手かざし検出を行うことで, 誤検出を減らす. このとき, 円の中心はコマンド 空間の中心で，半径は設置されたコマンド空間の中心から最も離れた頂点までの距離である.

\section{5. 実 験}

\section{$5 \cdot 1$ 家電操作システムの構築}

提案する家電操作システムを図 12 に示寸様に構築した. 四隅に設置したカメラによりユーザの手振りを認識し, コマンド空間を展開する.使用したカメラは Axis 233D ネットワークドームカメラである.画角は $55.8^{\circ} \times 43.3^{\circ}$, 画像の解像度は $640 \times 480$, 低解像度化した画像の解像度は $80 \times 60$ である. 実験対象としたコマンド空間は 1 番 から 6 番である. 実験の様子を図 13 に示す.

\section{$5 \cdot 2$ 手かざしの認識率検証実験}

$3 \cdot 1$ 節で述べたユーザが設定可能な擬似相対座標系の設定精度を検証した. コマンド空間の展開と手かざしの 精度を検証するため, 手振りでコマンド空間を構築し手かざしによる家電操作を行う一連の動作を 20 回行い, そ の認識率を評価した．本システムの操作経験がある被験者 1 人を対象とし，図 12 に示す位置で実験を行った.

提案手法のコマンド空間の認識率を表 1 に示す，平均認識率は $92.5 \%$ \%あり，全てのコマンド空間で認識率 $80 \%$ 以上の結果が得られた。 なお，コマンド空間位置の判断ミスで，コマンド空間が展開された位置と違う位置 に手かざしをしたため, 認識率が低下寸ることが実験中にあった.

\section{$5 \cdot 3$ 手かざしと手振りの操作時間比較実験}

Table 1 Recognition rate for each command space

\begin{tabular}{|c|c|}
\hline Command space & Recognition rate [\%] \\
\hline 1 & 90.0 \\
\hline 2 & 95.0 \\
\hline 3 & 100.0 \\
\hline 4 & 80.0 \\
\hline 5 & 100.0 \\
\hline 6 & 90.0 \\
\hline Average & 92.5 \\
\hline
\end{tabular}

Table 2 Time required for operation

\begin{tabular}{|c|c|c|}
\hline Times & Positioning [s] & Waving [s] \\
\hline 1 & 12.03 & 24.2 \\
\hline 2 & 9.28 & 25.3 \\
\hline 3 & 9.14 & 21.4 \\
\hline 4 & 10.1 & 21.0 \\
\hline 5 & 11.98 & 25.7 \\
\hline 6 & 12.51 & 24.5 \\
\hline 7 & 12.8 & 23.5 \\
\hline 8 & 10.8 & 23.2 \\
\hline 9 & 12.18 & 26.1 \\
\hline 10 & 10.95 & 24.2 \\
\hline Average & 11.2 & 23.9 \\
\hline
\end{tabular}


Table 3 Recognition rate for each subject

\begin{tabular}{|c|c|}
\hline Subject & Recognition rate \\
\hline 1 & $93.3 \%$ \\
\hline 2 & $86.7 \%$ \\
\hline 3 & $83.3 \%$ \\
\hline 4 & $96.7 \%$ \\
\hline 5 & $73.3 \%$ \\
\hline Average & $86.7 \%$ \\
\hline
\end{tabular}

Table 4 Recognition rate for each command space

\begin{tabular}{|c|c|}
\hline Command space & Recognition rate \\
\hline 1 & $96.0 \%$ \\
\hline 2 & $96.0 \%$ \\
\hline 3 & $80.0 \%$ \\
\hline 4 & $84.0 \%$ \\
\hline 5 & $84.0 \%$ \\
\hline 6 & $80.0 \%$ \\
\hline
\end{tabular}

手かざしと手振りでの家電操作するための時間の比較実験を行った．展開されたコマンド空間で手かざしと手 振り（従来手法）で 6 つのコマンド操作を 10 回行い，操作時間を評価した.

操作時間の比較結果を表 2 に示寸. 手かざしの平均操作時間は $11.2 \mathrm{~s}$, 手振りの平均操作時間は $23.9 \mathrm{~s}$ であった. 手かざし操作は手振り操作より $53 \%$ 高速化できた. 従来の手振り操作に代わり, より簡単なジェスチャで高速に 検出することが実現できた.

\section{$5 \cdot 4$ 未経験者における認識率検証実験}

被験者を増やし, 提案手法の検証実験を行った. 図 12 に示した位置で固定されているコマンド空間に対し, 各 コマンドで 5 回ずつ手かざしを行い, 認識率を調べた. 被験者は 20 代男性 5 名で, 全員システムの未経験者であ る．実験を行う前に，実験に当たって大まかなコマンド空間の配置説明を行った.

表 3 に被験者毎の認識率を，表 4 にコマンド空間毎の認識率を示寸．平均認識率は，86.7\%であり，ほぼ $80 \%$ を上回る結果となったが，被験者によってばらつきが大きい結果となっている．コマンド空間毎の認識率はす心゙ て $80 \%$ 上回るが，3番と 6 番のコマンド空間についてはほかのコマンド空間より検出率が低くなっている.こ れは，被験者が提案システムに対し展開されたコマンド空間の位置を正しく把握できず，間違えた位置に手をか ざすことがあり，認識率の低下につながったと思われる.

\section{$5 \cdot 5$ 考察}

手振りと比べ，操作時間が半分以下になったこと，また手を動かし続ける必要のある手振りに対して手かざし はその必要がないことから，提案手法では，従来手法より操作負担が軽減したと考えられる．また，提案システ ムのコマンド空間では，一辺 $300 \mathrm{~mm}$ の立方体を図 7 に示したように配置している. 人間生活工学研究センター による 70 代男女の手可達域に関する統計データ（人間生活工学研究センター，2021）と比べると，コマンド空間 のほとんどが「楽」の範囲内にあるため，本システムのコマンド空間は高齢者にとっても無理のない範囲である と考えられる. ただし，操作時間や手可達域以外にも操作性に影響を与える項目はあると考えられ，今後高齢者 を対象とした評価実験を行う必要がある.

また, 提案システムの平均認識率は, 従来研究(Kano et al., 2018)の 94\%から 86.7\%に低下した. 従来研究では, SUS(System Usability Scale) (Brooke, 1996)を用いてシステムのユーザビリティを評価した結果, SUS の平均スコア 
より若干低い程度であった．提案システムの認識率を従来研究と同程度にまで向上させることで，より高いユー ザビリティを実現できると考えられる.

\section{6. 結論}

本研究では，擬似相対座標系と手かざしを導入することで，コマンド空間の展開位置に対する制限が少ない， 簡単なジェスチャで操作できる家電操作システムを構築した. 操作精度と時間の評価実験を行った結果, 8 割以 上の認識率が得られ，また従来手法と比べ 2 倍以上高速化していることを示した．また，未経験者における実験 から, 未経験者でも固定されたコマンド空間に対し認識率 80 \%以上の結果を得られた. しかし, 本システムでは, コマンド空間を消去する手順を忘れると, 他の場所での家電操作ができず, 改善が必要である.

今後は, 本研究で得られた平均 $86.7 \%$ の手かざし認識率を向上する必要があると考えられる. また, 操作速度 は大幅に向上したとは言え，リモコン操作より高速とは言えず，リモコン操作と比較したユーザビリティの評価 も行う必要がある.ささらに, 上述の通り, 高齢者を対象とする実験を行い, 本システムの使い易さを検証したい. また，夜間でも家電操作を可能にするために，赤外線照明や赤外線カメラなどの導入も検討する.

\section{文献}

Bt Aripin, N. and Othman, M. B., Voice control of home appliances using android, 2014 Electrical Power, Electronics, Communicatons, Control and Informatics Seminar (EECCIS) (2014), pp. 142-146.

浅野秀扸, 永易武, 織茂達也, 寺林賢司, 太田陸, 梅田和昇, フーリエ変換を用いた指振り検出と機器操作への応 用, 精密工学会誌, Vol.79, No.6 (2013), pp.565-570.

Brooke, J., Sus-a quick and dirty usability scale, Usability evaluation in industry (1996), pp.189-194.

人間生活工学研究センター，高齢者身体機能データベース 動作特性-平成 10 年度 NEDO533 人計測- : available from<https://www.hql.jp/database/cat/senior/funcdb/result_dousa/>, (2021 年 3 月 13 日).

Hsieh, C., Liou, D. and Lee, D., A real time hand gesture recognition system using motion history image, 2010 2nd International Conference on Signal Processing Systems (2010), pp. 394-398.

今村勇也, 永易武, 浅野秀胤, 寺林賢司, 梅田和昇，コマンド空間を用いた家電操作システムの改良と実験による 認識率の検証, 第 31 回日本ロボット学会学術講演会予稿集, 2D2-03 (2013).

入江耕太, 梅田和昇, 濃淡值の時系列変化を利用した画像からの手振りの検出, 日本ロボット学会誌, Vol. 21 , No. 8 (2003), pp. 923-931.

入江耕太, 若林直弘, 梅田和昇, ジェスチャ認識基づくインテリジェントルームの構築, 日本機械学会論文集 C 編, Vol. 73, No.725 (2007), pp. 258-265.

Kaneda, S., Kubota, Y., Kurokawa, T. and Furuhata, T., Hand-gesture recognition system by using microwave doppler sensors, 2015 IEEE 39th Annual Computer Software and Applications Conference (2015), pp. 211-216.

Kano, T., Kawamura, T., Asano, H., Nagayasu, T. and Umeda, K., Hand waving in command spaces: a framework for operating home appliances, advanced robotics, Vol. 32, No. 18 (2018), pp. 999-1006.

森武俊, 佐藤知正, ロボティックローム 1・2・3 の開発, 電子情報通信学会誌, Vol. 91, No. 5 (2008), pp. 402-410.

Muranaka, Y., Al-Sada, M. and Nakajima, T., A home appliance control system with hand gesture based on pose estimation, 2020 IEEE 9th Global Conference on Consumer Electronics (GCCE) (2020), pp. 752-755.

Nakayama, H., Yabuki, N., Inoue, H., Sumi, Y. and Tsukutani, T., A control system for electrical appliances using eye-gaze input, 2012 International Symposium on Intelligent Signal Processing and Communications Systems (2012), pp. 410-413.

Niitsuma, M., Kobayashi, H. and Shiraishi, A., Enhancement of spatial memory for applying to sequential activity, Journal of Advanced Sciences, Vol. 9, No. 1 (2012), pp. 121-137.

Trong, K. N., Bui, H. and Pham, C., Recognizing hand gestures for controlling home appliances with mobile sensors, 2019 11th International Conference on Knowledge and Systems Engineering (KSE) (2019), pp. 1-7.

Yan, S., Ji, Y. and Umeda, K., a system for home appliance operation by hand waving in a user-definable command space, Fourteenth International Conference on Quality Control by Artificial Vision, Vol. 11172, No. 14 (2019). 


\section{References}

Bt Aripin, N. and Othman, M. B., Voice control of home appliances using android, 2014 Electrical Power, Electronics, Communicatons, Control and Informatics Seminar (EECCIS) (2014), pp. 142-146.

Asano, H., Nagayasu, T., Orimoshi, T., Terabayashi, K., Ota, R. and Umeda, K., Detection of finger-waving movements using discrete fourier transform and its application for equipments control, Journal of the Japan Society for Precision Engineering, Vol. 79, No.6 (2013), pp. 565-570 (in Japanese).

Brooke, J., Sus-a quick and dirty usability scale, Usability evaluation in industry (1996), pp.189-194.

Database for Human Life Engineering, Database for physical functions of the elderly Operating characteristics: 533 measurements by NEDO in 1998: available from<https://www.hql.jp/database/cat/senior/funcdb/result_dousa/>, (13 March, 2021).

Hsieh, C., Liou, D. and Lee, D., A real time hand gesture recognition system using motion history image, 2010 2nd International Conference on Signal Processing Systems (2010), pp. 394-398.

Imamura, Y., Nagayasu, T., Asano, H., Terabayashi, K., and Umeda, K., Improvement of home appliance operation system using command space and verification of recognition rate by experiment, The 31st Annual Conference of the Robotics Society of Japan, 2D2-03 (2013) (in Japanese).

Irie, K. and Umeda, K., Detection of waving hands from images using time series of intensity values, Journal of the Robotics Society of Japan, Vol. 21, No. 8 (2003), pp. 923-931 (in Japanese).

Irie, K., Wakabayashi, N., and Umeda, K., Construction of an intelligent room based on gesture recognition, Transactions of the Japan Society of Mechanical Engineers, Series C, Vol. 73, No.725 (2007), pp. 258-265 (in Japanese).

Kaneda, S., Kubota, Y., Kurokawa, T. and Furuhata, T., Hand-gesture recognition system by using microwave doppler sensors, 2015 IEEE 39th Annual Computer Software and Applications Conference (2015), pp. 211-216.

Kano, T., Kawamura, T., Asano, H., Nagayasu, T. and Umeda, K., Hand waving in command spaces: a framework for operating home appliances, Advanced Robotics, Vol. 32, No. 18 (2018), pp. 999-1006.

Mori, T. and Sato, T., Development of robotic loams 1, 2 and 3, The journal of the Institute of Electronics, Information and Communication Engineers, Information and Communication Engineers, Vol. 91, No. 5 (2008), pp. $402-410$ (in Japanese).

Muranaka, Y., Al-Sada, M. and Nakajima, T., A home appliance control system with hand gesture based on pose estimation, 2020 IEEE 9th Global Conference on Consumer Electronics (GCCE) (2020), pp. 752-755.

Nakayama, H., Yabuki, N., Inoue, H., Sumi, Y. and Tsukutani, T., A control system for electrical appliances using eye-gaze input, 2012 International Symposium on Intelligent Signal Processing and Communications Systems (2012), pp. 410-413.

Niitsuma, M., Kobayashi, H. and Shiraishi, A., Enhancement of spatial memory for applying to sequential activity, Journal of Advanced Sciences, Vol. 9, No. 1 (2012), pp. 121-137.

Trong, K. N., Bui, H. and Pham, C., Recognizing hand gestures for controlling home appliances with mobile sensors, 2019 11th International Conference on Knowledge and Systems Engineering (KSE) (2019), pp. 1-7.

Yan, S., Ji, Y. and Umeda, K., A system for home appliance operation by hand waving in a user-definable command space, Fourteenth International Conference on Quality Control by Artificial Vision, Vol. 11172, No. 14 (2019). 